\title{
Deep Learning untuk Klasifikasi Diabetic Retinopathy menggunakan Model EfficientNet
}

\section{SYAMSUL RIZAL, NUR IBRAHIM, NOR KUMALASARI CAESAR PRATIWI, SOFIA SAIDAH, RADEN YUNENDAH NUR FU'ADAH}

Teknik Telekomunikasi Fakultas Teknik Elektro Universitas Telkom, Indonesia Email: syamsul@telkomuniversity.ac.id

Received 16 Juli 2020 | Revised 2 Agustus 2020 | Accepted 15 Agustus 2020

\begin{abstract}
ABSTRAK
Diabetic Retinopathy merupakan penyakit yang dapat mengakibatkan kebutaan mata yang disebabkan oleh adanya komplikasi penyakit diabetes melitus. Oleh karena itu mendeteksi secara dini sangat diperlukan untuk mencegah bertambah parahnya penyakit tersebut. Penelitian ini merancang sebuah sistem yang dapat mendeteksi Diabetic Retinopathy berbasis Deep Learning dengan menggunakan Convolutional Neural Network (CNN). EfficientNet model digunakan untuk melatih dataset yang telah di pre-prosesing sebelumnya. Hasil dari penelitian tersebut didapatkan akurasi sebesar $79.8 \%$ yang dapat mengklasifikasi 5 level penyakit Diabetic Retinopathy.
\end{abstract}

Kata kunci: Diabetic Retinopathy, Deep Learning, CNN, EfficientNet, Diabetic Classification

\begin{abstract}
Diabetic Retinopathy is a diseases which can cause blindness in the eyes because of the complications of diabetes mellitus. Therefore, an early detection for this diseases is very important to prevent the diseases become severe. This research builds the system which can detect the Diabetic Retinopathy based on Deep Learning by using Convolutional Neural Network (CNN). EfficientNet model is used to trained the dataset which have been pre-prossed. The result shows that the system can clasiffy the 5 level of Diabetic Retinopathy with accuracy $79.8 \%$.
\end{abstract}

Keywords: Diabetic Retinopathy, Deep Learning, CNN, EfficientNet, Diabetic Classification 


\section{PENDAHULUAN}

Diabetic Retinopathy merupakan suatu penyakit yang dapat menyebabkan kebutaan pada penderitanya. Hal ini disebabkan karenanya terdapatnya sejumlah luka pada mata yang dapat merusak retina pada mata. Pada tahap awal, terjadinya pelebaran pembuluh darah pada mata, yang selanjutkan jika dibiarkan akan terbentuk pembuluh darah baru yang dapat menutup retina mata yang berakhir pada kebutaan. Diabetic Retinopathy dibagi menjadi 2 kelas yaitu non-proliferative Diabetic Retinopathy (NPDR), dan proliferative Diabetic Retinopathy (PDR). NPDR adalah tahap awal pada Diabetic Retinopathy yang membentuk microaneurysms. PDR adalah level akhir pada Diabetic Retinopathy yang berarti kerusakan pada mata sudah parah yang dapat menyebabkan pecahnya pembuluh darah pada mata (Duh, 2017), (Wu, 2013), (Qummar, 2019). Sedangkan berdasarkan tingkatannya, menurut para ahli Opthalmologist, Diabetic Retinopathy diklasifikasikan kedalam 4 level kondisi: 1) Mild Non-proliferative, 2) Moderate Non-proliferative, 3) Severe Non-proliferative, dan 4) Proliferative.

Banyak peneliti yang telah membuat sistem yang dapat mendeteksi penyakit tersebut dengan menggunakan beberapa teknik machine learning. Pada jurnal yang berjudul "Classification of Diabetic Retinopathy and Normal Retinal Images using CNN and SVM" telah melakukan klasifikasi 2 kelas yaitu normal dan severe NPDR dengan menggunakan CNN dan SVM sebagai model klasifikasinya. Dataset yang didapat berasal dari Messidor database (base 12 dan base 13) yang masing-masing memiliki 77 dan 70 gambar dataset. Metode transfer learning digunakan untuk mengambil ciri pada gambar yang berasal dari model GoogleNet, DenseNet, dan ResNet yang kemudian dilakukan klasifikasi menggunakan SVM. Hasil penelitian ini didapatkan akurasi sebesar $95.83 \%$ dan $95.24 \%$ dari masing-masing dataset (base 12 dan base 13). Pada penelitian ini hanya dilakukan klasifikasi 2 kelas antara normal dan severe NPDR yang tentu saja akan sangat mudah untuk ditemukan cirinya, sehingga nilai akurasi akan sangat tinggi. (Qomariah, 2019).

Penelitian pada jurnal yang berjudul "Convolutional Neural Networks for Diabetic Retinopathy" telah melakukan klasifikasi 5 level Diabetic Retinopathy. Hasil pada penelitian ini mendapatkan akurasi sebesar $75 \%$. Pada jurnal ini tidak ditampilkan hasil training dan testing, sehingga sulit untuk dicek apakah hasilnya terdapat overfitting atau tidak. Serta augmentasi juga dilakukan untuk memperbanyak jumlah dataset yang ada untuk dijadikan data latih. (Pratt, 2016). Selain itu, penelitian lain dengan judul "Diabetic Retinopathy Stage Classification using Convolutional Neural Networks" melakukan klasifikasi 5 level Diabetic Retinopathy dengan menggunakan 3 model yang berbeda yaitu, AlexNet, VGG16, dan InceptionNet V3. Akurasi tertinggi dari ketiga model tersebut adalah 63.23\% (Wang, 2018). Pada jurnal "Diabetic Retinopathy Stage Classification using CNN" mendapatkan akurasi sebesar $80.1 \%$ dengan 5 kelas. Metode yang digunakan adalah menggabungkan 3 jenis model yaitu AlexNet, VGG16, dan InceptionNet V3. Namun pada penelitian ini hanya menggunakan 100 data latih untuk masing-masing kelas. Jumlah dataset yang digunakan terbilang sedikit, sehingga akan sangat sulit jika dilakukan test dengan data uji yang baru. (Nikhil, 2019).

Berdasarkan dari penelitian tersebut, maka pada penelitian ini dibuat untuk melengkapi dari kekurangan dari system model diatas. Sistem yang dibuat merupakan klasifikasi 5 kelas penyakit Diabetic Retinopathy dengan menggunakan CNN dengan model EfficientNet yang memiliki tingkat akurasi cukup tinggi dibandingkan dengan metode sebelumnya yaitu sebesar $79.8 \%$. 


\section{METODOLOGI PENELITIAN}

Tujuan dari penelitian ini adalah mendeteksi secara dini Diabetic Retinopathy pada pasien sebagai upaya pencegahan bertambah parahnya penyakit tersebut, serta mampu mengelompokkannya berdasarkan lima level kondisi, yaitu No_DR (tanpa Diabetic Retinophaty), Mild (ringan), Moderate (sedang), Severe (parah), Proliferate_DR (sangat parah). Berikut adalah keseluruhan diagram sistem pada penelitian ini.

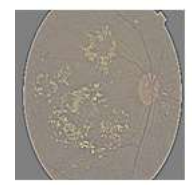

Input

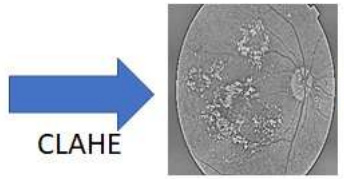

CLAHE

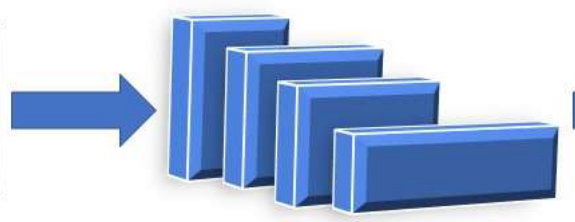

Ekstraksi Ciri menggunakan EfficientNet

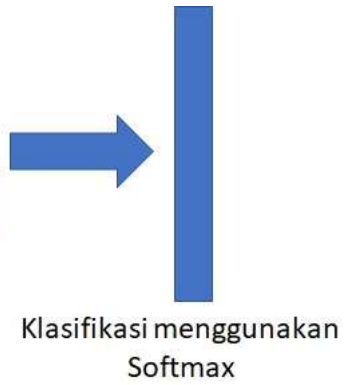

\section{Gambar 1. Blok Diagram Sistem}

\subsection{Pemilihan Citra Input}

Citra input (dataset) yang digunakan didapatkan dari Kaggle yaitu gaussian filter retina image for Diabetic Retinopathy dataset. Dataset terdiri dari 5 kelas, yaitu No_DR, Mild, Moderate, Severe, dan Proliferate_DR. Gambar telah di-resize dengan ukuran 224 x 244 piksel sehingga telah siap digunakan untuk dilatih menggunakan model deep learning. Setiap kelas memiliki jumlah gambar yang berbeda, seperti yang terlihat pada Table 1.

Tabel 1. Jumlah dataset tiap kelas

\begin{tabular}{|c|c|c|}
\hline No. & Kelas & Jumlah data \\
\hline 1 & No_DR & 1805 \\
\hline 2 & Mild & 370 \\
\hline 3 & Moderate & 999 \\
\hline 4 & Severe & 193 \\
\hline 5 & Proliferate_DR & 295 \\
\hline \multicolumn{2}{|c|}{ Total } & $\mathbf{3 6 6 2}$ \\
\hline
\end{tabular}

Gambar 2 adalah contoh gambar untuk tiap kelas dari dataset yang digunakan.

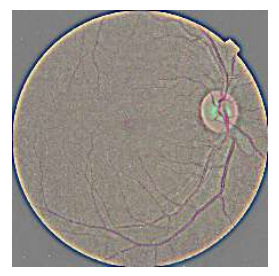

(a)

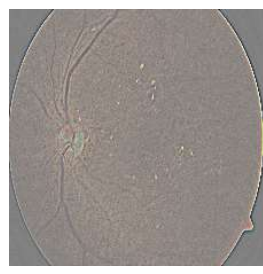

(b)

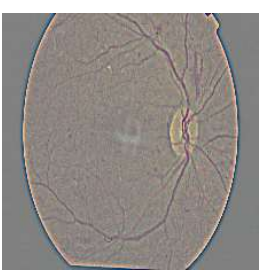

(c)

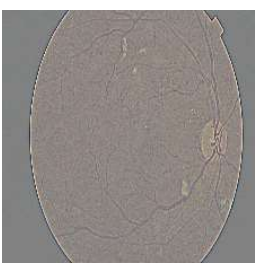

(d)

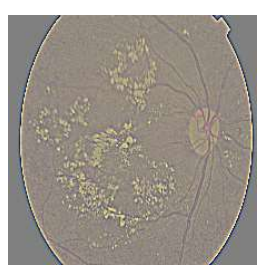

(e)

Gambar 2. Kelas Diabetic Retinopathy dengan Gaussian Filter a) No_DR, b) Mild, c) Moderate, d) Severe, e) Proliferate_DR 
Gambar 2 merupakan dari kelima kelas Diabetic Retinopathy yang sudah melalui proses Gaussian Filter. Gambar 5(a) merupakan gambar mata yang normal, sedangkan Gambar 5(b) sampai dengan Gambar 5(d) merupakan gambar mata yang memiliki kelas non proliferate dari tingkat sedang, menengah dan parah secara berurutan. Non proliferate merupakan tahapan awal untuk mendeteksi diabetes melalui mata sehingga dapat dilakukan tindakan pengobatan secara dini sebelum penyakit bertambah parah. Pada tahapan ini, terjadi penambahan microaneurysm yang bentuknya seperti balon pada mata. Untuk gambar $5 e$ merupakan gambar mata yang memiliki tingkat yang paling parah. Pada tahapan ini mata akan membentuk pembuluh darah baru yang sangat tidak normal. Pembuluh darah ini akan berkembang sehingga menutupi retina mata. Sebenarnya pada tahapan ini tidak akan menyebabkan kebutaan, namun pembuluh darah ini sangatlah tipis, sehingga jika terjadi pecahnya pembuluh darah tersebut maka akan menyebabkan kebutaan.

\subsection{Pre-processing}

Sebelum dimasukkan ke dalam model Deep Learning, perlu dilakukan pre-processing pada dataset citra input. Penulis menggunakan Contrast Limited Adapt ive Histogram Equalization (CLAHE) seperti yang terlihat pada Gambar 3, sebagai metode untuk meningkatkan kontras citra (Yadav, 2014), (Campos, 2019). CLAHE merupakan metode untuk meningkatkan untuk meningkatkan kontras pada citra. Berbeda dengan metode lain yang dapat meningkatkan kontrak citra lainnya, metode ini tidak akan meningkatkan kontras noise pada gambar. Hal ini dapat dilakukan dengan menentukan nilai clip limit (batas ambang) untuk dilakukan pemotongan dari bagian citra yang tidak diperlukan.

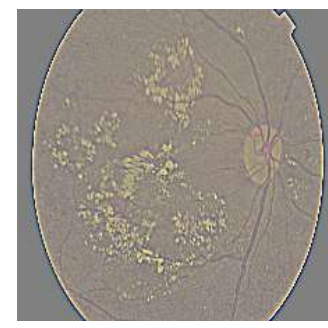

(a)

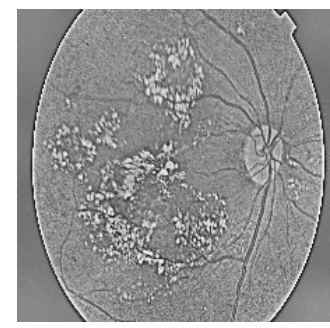

(b)

Gambar 3. Citra yang telah dilakukan pre-processing a) sebelum menggunakan CLAHE, b) setelah menggunakan CLAHE

\subsection{Perancangan dan Pelatihan Sistem}

Sistem pada penelitian ini dirancang menggunakan model EfficientNet. Model ini merupakan pengembangan dari model-model lainnya dengan meningkatkan dimensi baik itu dari kedalaman layer maupun lebarnya layer (Tan, 2019), (Qidong, 2020). Citra hasil CLAHE pada tahap sebelumnya akan dijadikan masukan untuk model EfficientNet untuk mendapatkan bobot yang tepat untuk masing-masing neuron-nya.

Penulis menggunakan EfficientNet sebagai model dasar yang dapat dilihat pada Gambar 4. Sebelum mencapai layer klasifikasi, penulis melakukan penambahan beberapa layer yang terlihat pada Tabel 2 dan Gambar 5. 
Deep Learning untuk Klasifikasi Diabetic Retinopathy menggunakan Model EfficientNet

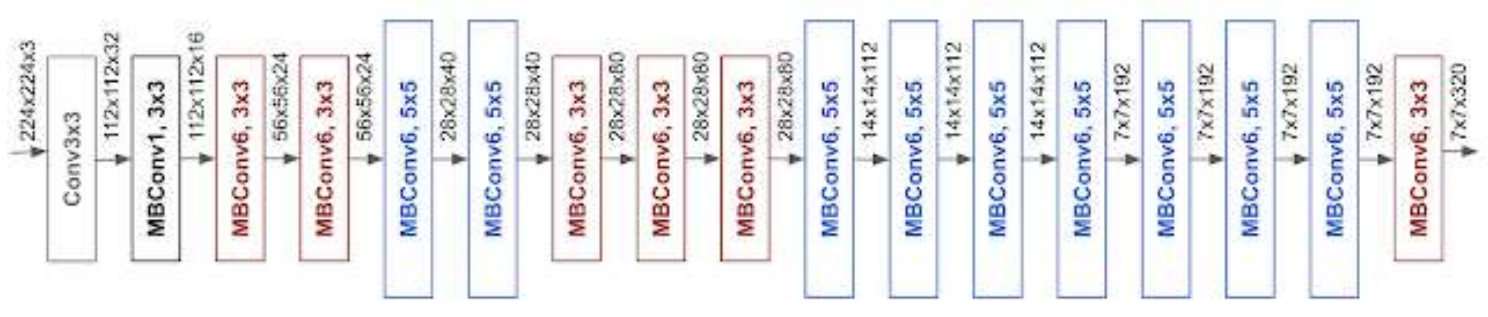

Gambar 4. EfficientNet Model

Tabel 2. Layer Klasifikasi pada Sistem Model

\begin{tabular}{|c|c|c|}
\hline Layer & Output & Parameter \\
\hline Global max pooling 2D & 1280 & 0 \\
\hline Dropout & 1280 & 0 \\
\hline Dense & 128 & 163968 \\
\hline RELU & 128 & 0 \\
\hline Dropout & 128 & 0 \\
\hline Dense & 5 & 645 \\
\hline Softmax & 5 & 0 \\
\hline
\end{tabular}

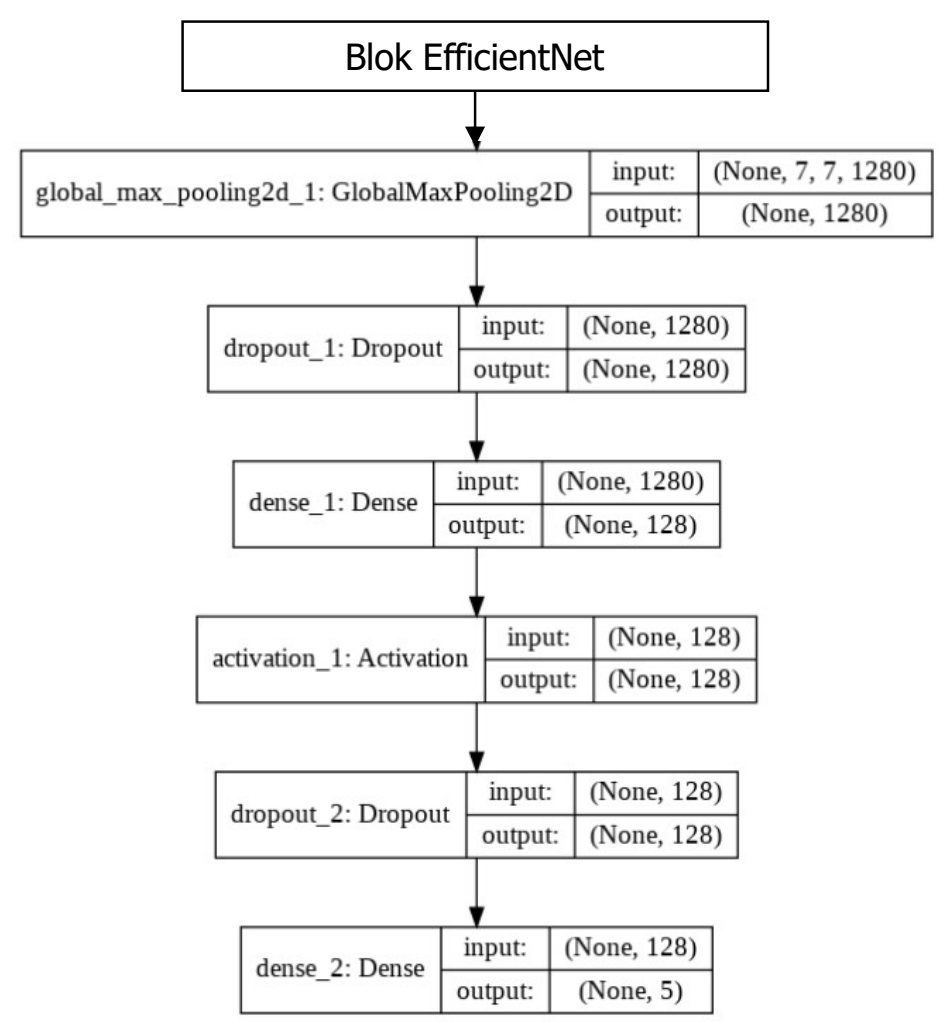

Gambar 5. Plot Usulan Model EfficientNet

Pada blok EfficientNet terdapat layer yang berisikan convolutional neural network (CNN) layer dan Pooling layer. CNN adalah sebuah layer yang akan meningkatkan dimensi citra input menjadi beberapa dimensi sesuai dengan model yang dibuat. CNN adalah sebuah filter yang akan dikonvolusikan terhadap citra sebelumnya, yang kemudian citra tersebut akan menghasilkan multidimensi citra (Zebin, 2019), (Gonzalez, 2018). 
Pooling layer digunakan untuk mereduksi resolusi citra yang tujuannya untuk mendapat gambaran besar dari citra tersebut. Pooling layer terdiri dari 2 tipe, yaitu Max pooling dan Average Pooling. Max pooling adalah fungsi yang mencari nilai terbesar pada ukuran pooling tersebut, sedangkan average pooling mencari nilai rata-rata dari keseluruhan nilai pada pooling (Albawi, 2018), (Ahmadi, 2018). Gambar 6 menjelaskan mengenai perbedaan Max pooling dan Average pooling. Pada contoh ini terdapat citra berukuran 4x4 pixel. Setiap pixel memiliki nilai yang berbeda, dan filter Max Pooling yang digunakan sebesar $2 \times 2$ dengan stride adalah 2. Stride adalah parameter yang akan menggeser filter sesuai dengan nilainya, dalam contoh ini adalah 2 pixel. Tahap pertama dapat dilihat dengan filter yang berwarna biru, Max Pooling akan mengambil nilai terbesar dari potongan citra tersebut, yaitu 6 . Lalu filter akan bergeser ke kanan sebanyak 2 pixel (filter berwarna hijau). Lalu nilai maximum dari potongan citra tersebut akan diambil dan hasilnya akan diletakan disebelah kanan dari hasil filter sebelumnya. Berikut filter akan bergeser dari kiri ke kanan dan dari atas ke bawah sampai filter tersebut melewati seluruh citra. Untuk proses Average Pooling hampir sama dengan Max Pooling, hanya saja pada metode ini bukan nilai maksimum yang diambil, melainkan nilai ratarata dari keseluruhan pixel pada potongan citra tersebut.

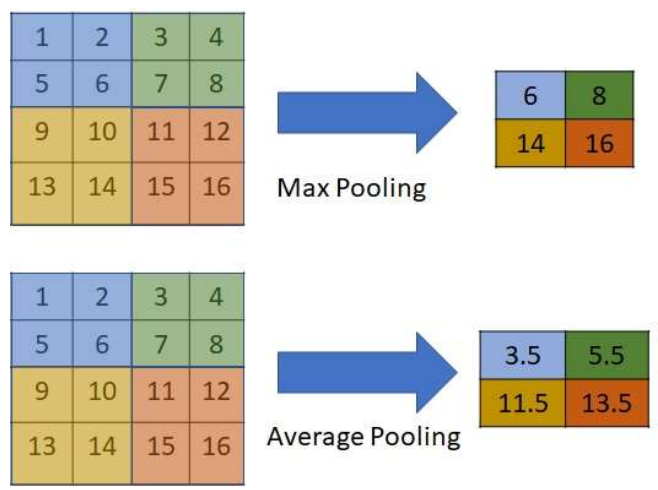

Gambar 6. Pooling Layer

Langkah terakhir adalah mengubah citra multidimensi menjadi 1 dimensi menggunakan fungsi flatten yang kemudian akan dilakukan proses klasifikasi 5 kelas dengan menggunakan aktivasi Softmax. Softmax adalah sebuah fungsi yang akan menghitung probabilitas untuk setiap kelasnya, dan kelas yang memiliki probabilitas yang paling tinggi akan dijadikan sebagai hasil prediksi.

\subsection{Training}

Pada proses pelatihan, dataset dibagi menjadi 2 untuk dijadikan data latih 75\%, dan data uji 25\%. Data Uji diperlukan untuk menvalidasi akurasi dari model yang telah dibuat. Beberapa skenario akan dilakukan untuk dijadikan pembanding dan mencari nilai akurasi terbaik.

Skenario 1 dilakukan pelatihan model dengan ukuran gambar $224 \times 224$ dengan data original, skenario 2 dilakukan resize citra dengan ukuran $128 \times 128$ masih menggunakan citra original. Untuk skenario 3 dan 4 dilakukan pelatihan dengan ukuran citra 224 x 224 serta $128 \times 128$ secara berturut-turut dengan menggunakan citra yang telah di pre-processing menggunakan CLAHE.

\subsection{Parameter}

Parameter yang dipasang pada model ini menggunakan Stochastic Gradient Decent (SGD) sebagai optimizer nya dengan learning rate 0.001 dan momentum sebesar 0.9 . Loss yang digunakan adalah categorical crossentropy. Pelatihan akan dilakukan proses iterasi sebanyak 
50 epoch dengan ukuran batch 32. Pelatihan ini dilakuan proses earlystopping agar pelatihan diberhentikan jika nilai validasi akurasi sudah tidak dapat meningkat lagi. Hal ini dilakukan juga untuk menghindari terjadinya overfitting. Overfitting akan menyebabkan sebuah system hanya mengenali data yang dilatih saja. Jika ada masukan data baru, maka system akan kesulitan mengklasifikasi data tersebut sehingga performansi system tersebut dapat dikatakan rendah.

\section{ANALISIS SISTEM DAN HASIL}

Penelitian ini memiliki 4 skenario yang memiliki perbedaan dari beberapa parameter seperti ukuran dan pre-processing citra untuk mengetahui parameter yang dapat mencapai tingkat akurasi maksimal dari model yang diusulkan menggunakan EfficientNet. Adapun perbedaan masing-masing skenario dapat dilihat pada Tabel 3 berikut.

Tabel 3. Parameter pada Skenario Penelitian

\begin{tabular}{|c|c|c|}
\hline Skenario & Pre-processing & Ukuran Citra (Piksel) \\
\hline 1 & Citra Original & $224 \times 224$ \\
\hline 2 & Citra Original & $128 \times 128$ \\
\hline 3 & CLAHE & $224 \times 224$ \\
\hline 4 & CLAHE & $128 \times 128$ \\
\hline
\end{tabular}

Skenario 1 dan 2 merupakan pelatihan citra original dengan ukuran citra sebesar $224 \times 224$ piksel dan $128 \times 128$ piksel secara berurutan. Sedangkan pada skenario 3 dan 4 merupakan pelatihan dari citra yang telah di pre-processing menggunakan CLAHE dengan ukuran citra 224 x 224 dan 128 x 128 piksel. Hal ini ditujukan untuk melihat perbedaan nilai akurasi dari setiap skenarionya dan mendapatkan nilai akurasi yang maksimal pada penelitian ini.

\subsection{Skenario 1: pelatihan citra original dengan ukuran citra 224 x 224 piksel}

Pada skenario ini dilakukan pengujian sistem untuk citra original dengan ukuran $224 \times 224$ piksel.

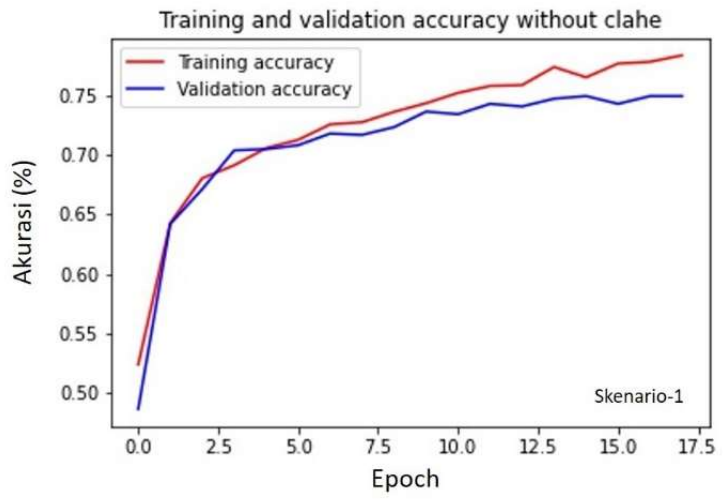

(a) akurasi

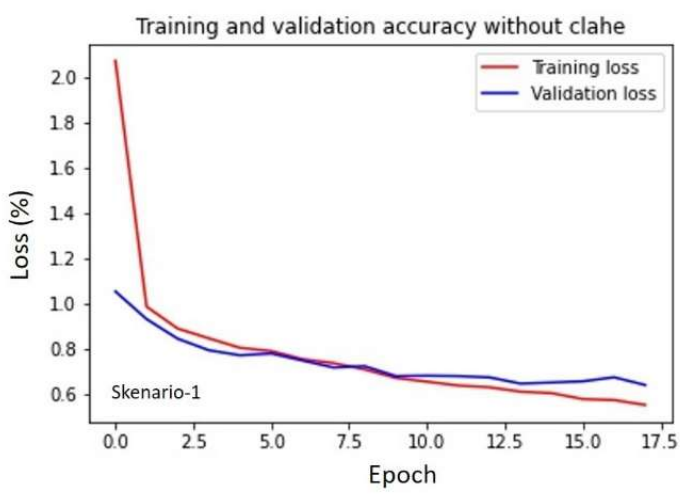

(b) Loss

Gambar 7. Hasil dari Pelatihan dan Pengujian menggunakan Citra Original dengan Ukuran Citra $224 \times 224$

Terlihat pada Gambar 7, nilai validasi akurasi sebesar 75\%. Nilai tersebut dicapai setelah melakukan 17 epoch. Training akurasi memiliki nilai sekitar $78 \%$ yang tidak berbeda jauh 
dengan validasi akurasi. Hal ini dapat disimpulkan tidak terjadi overfitting pada sistem yang telah dibuat.

\subsection{Skenario 2 : pelatihan citra original dengan ukuran citra $128 \times 128$ piksel}

Pada skenario ini dilakukan pengujian sistem dengan merubah ukuran citra menjadi $128 \times 128$ dengan menggunakan citra original. Hasil dari pengujian ini dapat dilihat pada Gambar 8.

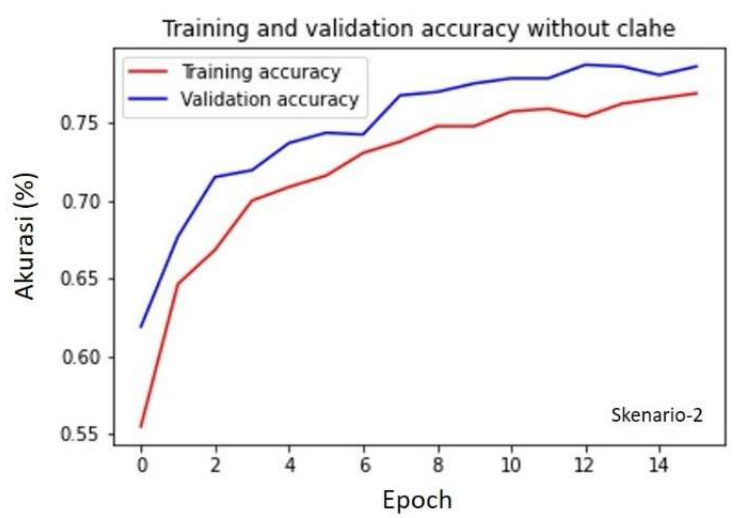

(a) akurasi

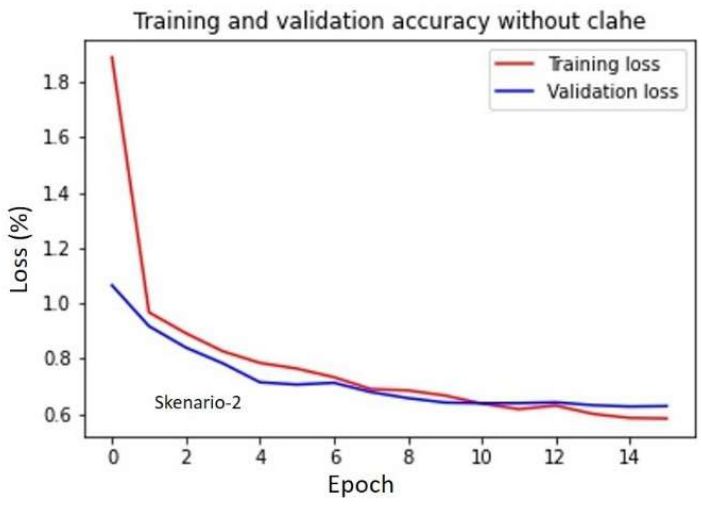

(b) loss

\section{Gambar 8. Hasil dari Pelatihan dan Pengujian Menggunakan Citra Original dengan Ukuran} Citra $128 \times 128$

Pada skenario ini didapatkan nilai validasi akurasi sebesar $78 \%$ dengan nilai loss 0.7 . Nilai akurasi meningkat dikarenakan ukuran gambar yang diperkecil, sehingga mempermudah sistem untuk mengambil ciri pada dataset. Pada hasil ini juga tidak terjadi overfitting yang berarti sistem dapat mengenali citra baru dengan tingkat akurasi $78 \%$. Selain itu nilai loss hanya dapat mencapai 0.7 , yang berarti masih banyak nilai yang tidak sesuai antara nilai prediksi dan nilai label atau groundtruth nya. Hal ini disebabkan optimizer SGD tidak dapat mencapai nilai global minima, sehingga nilai loss akan sulit mencapai dibawah angka 0.7.

\subsection{Skenario 3 : pelatihan citra CLAHE dengan ukuran citra 224 x 224 piksel}

Skenario 3 dilakukan dengan menggunakan dataset yang telah melalui proses CLAHE dengan ukuran citra 224 x 224. Gambar 9 adalah hasil dari pengujian dataset tersebut.

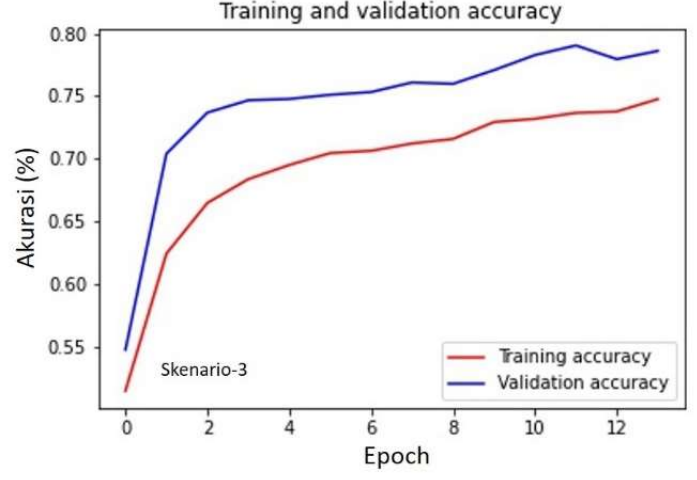

(a) akurasi

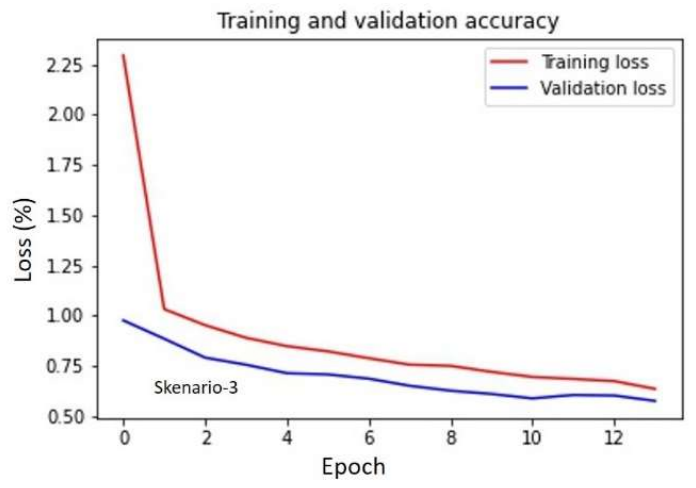

(b) loss

Gambar 9. Hasil dari Pelatihan dan Pengujian Menggunakan Citra CLAHE dengan Ukuran Citra $224 \times 224$ 
Hasil yang didapatkan pada scenario 3 ini memiliki tingkat akurasi sebesar 79.8\%, dengan loss 0.6. Skenario ini memiliki nilai akurasi yang terbaik jika dibandingkan dengan skenario lainnya. Meningkatnya tingkat akurasi pada skenario ini, dikarenakan citra telah dilakukan proses CLAHE terlebih dahulu sebelum dilakukan proses training dan uji. Dengan metode CLAHE, tingkat kontras citra akan semakin tajam. Sehingga sistem akan lebih mudah untuk mengambil ciri dari citra pada masing-masing kelas tersebut. Pada hasil ini tidak terdapat overfitting, dan akurasi didapat setelah melalui 13 epoch yang berarti proses pelatihan lebih cepat dibandingkan skenario lainnya.

Nilai loss terlihat masih dapat lebih rendah lagi jika dilanjutkan proses epoch training-nya, dapat dilihat dari Gambar 9(b). Namun proses pelatihan diberhentikan oleh sistem jika tidak ada peningkatan pada validasi akurasi. Hal ini dilakukan untuk mencegah terjadinya overfitting. Untuk itu perlu dilakukan pengganti loss dan optimizer yang tepat untuk menggunakan dataset ini.

\subsection{Skenario 4 : pelatihan citra CLAHE dengan ukuran citra 128 x 128 piksel}

Pada skenario terakhir ini dilakukan pelatihan dengan menggunakan citra CLAHE dengan ukuran citra 128 x 128. Hasil dari skenario ini dapat dilihat pada Gambar 10.

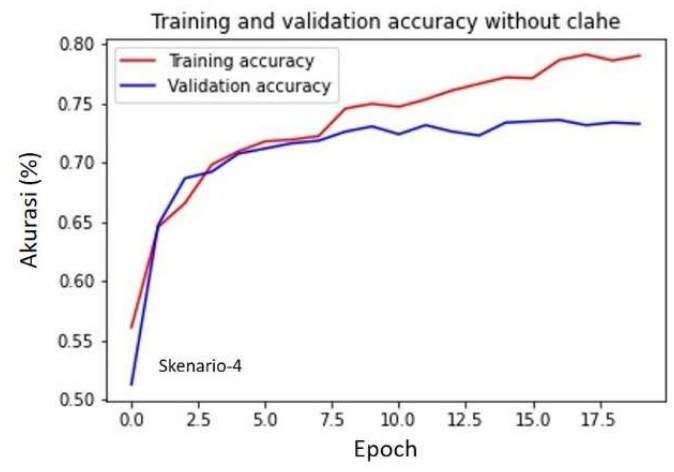

(a) akurasi

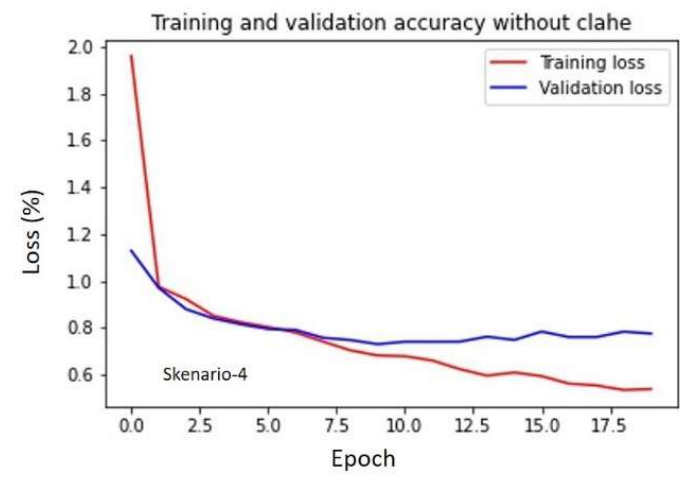

(b) loss

\section{Gambar 10. Hasil dari Pelatihan dan Pengujian Menggunakan Citra CLAHE dengan Ukuran Citra $128 \times 128$}

Dari Gambar 10 di atas dapat disimpulkan bahwa tingkat akurasi pada skenario ini memiliki nilai $73 \%$ pada validasi akurasinya. Hal ini disebabkan karena sebelumnya citra asli dilakukan proses CLAHE yang menyebabkan kontrak citra semakin tajam khususnya pada bagian bergaris pada citra. Sedangkan bagian secalin garis akan di redupkan. Sehingga ketika ukuran citra diperkecil dilakukannya proses CLAHE, maka akan banyak informasi yang hilang pada proses tersebut. Dengan demikian tidak disarankan untuk melakukan CLAHE dan resizing citra karena dapat menurunkan kualitas citra. Gambar 11 merupakan rangkuman untuk mempermudah melihat perbandingan nilai akurasi dari ke-empat skenario di atas. 


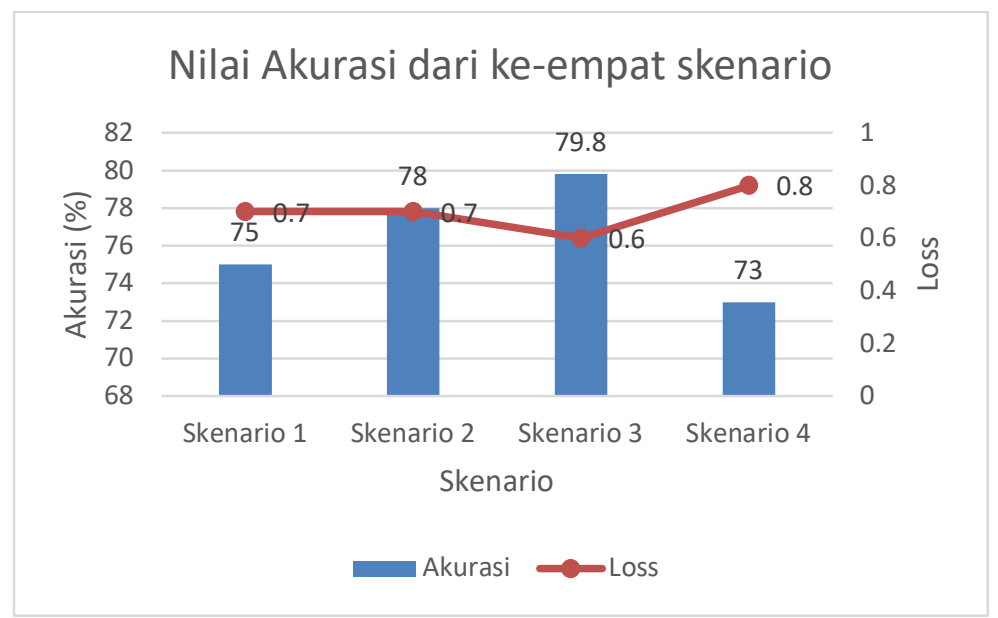

Gambar 11. Perbandingan Nilai Akurasi dan Loss dari Ke-Empat Skenario

Terlihat dari Gambar 11 bahwa nilai akurasi dan loss yang paling baik terdapat pada skenario 3, yaitu dengan menggunakan CLAHE pada tahap pre-processing-nya serta dengan menggunakan ukuran citra yang sebenarnya yaitu 224 x 224 .

\subsection{Confusion Matrix}

Gambar 12 adalah hasil confusion matrix terhadap data uji.

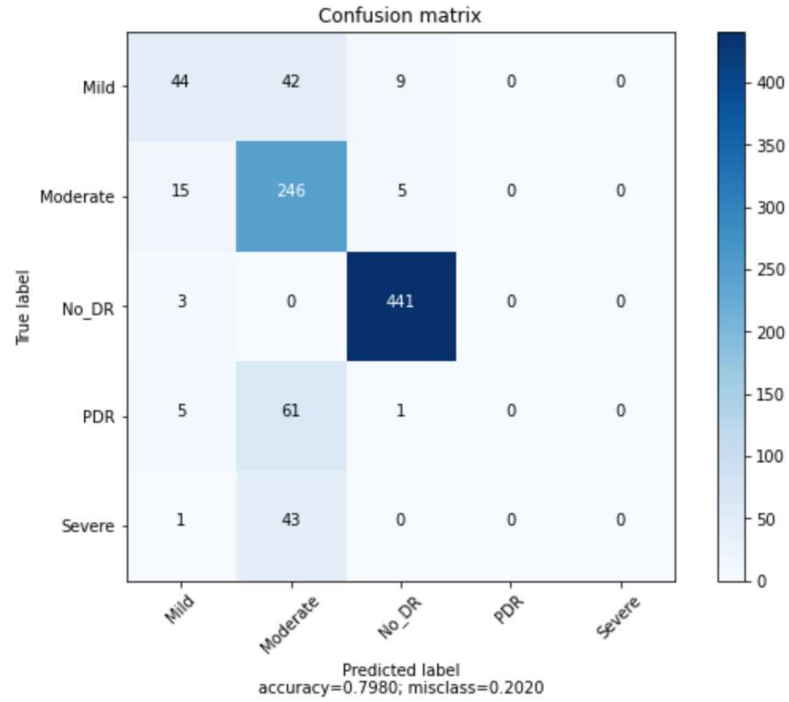

\section{Gambar 12. Confusion Matrix dari Data Uji}

Terlihat akurasi dari skenario 3 sebesar $79.8 \%$ untuk data uji. Selain itu perhitungan specificity dilakukan dan mendapatkan hasil sebesar 93.11\%, serta sensitivity dengan nilai $80 \%$. Sensitivity merupakan nilai benar positif terhadap nilai keseluruhan data yang benar, sedangkan specificity merupakan nilai prediksi negative terhadap nilai benar yang negative. Kedua parameter ini sangatlah penting untuk dihitung selain mencari nilai akurasi. Sensitivitas mengukur kemungkinan positif sebenarnya, dan spesfisitas mengukur probabilitas negative yang sebenarnya. Tes yang ideal harus mendapatkan nilai kedua parameter ini $100 \%$, namun sulit untuk mencapai nilai tersebut. Kedua parameter ini sangat penting untuk menguji keandalan hasil pengujian. 


\subsection{Perbandingan metode dengan penelitian sebelumnya}

Berikut adalah tabel untuk membandingkan nilai akurasi sistem model terhadap model lainnya.

Tabel 3. Perbandingan dengan Model Sebelumnya

\begin{tabular}{|c|c|c|c|}
\hline Reference & Metode & Jumlah Kelas & Akurasi \\
\hline Dinial, 2019 & $\begin{array}{c}\text { GoogleNet, DenseNet, dan } \\
\text { ResNet }\end{array}$ & 2 & $95.83 \%$ \\
\hline Harry, 2016 & CNN & 5 & $75 \%$ \\
\hline Xiaoliang, 2018 & AlexNet & 5 & $63.23 \%$ \\
\hline Nikhil, 2019 & $\begin{array}{c}\text { AlexNet, VGG16, dan } \\
\text { InceptionNet V3 }\end{array}$ & 5 & $80.1 \%$ \\
\hline \multicolumn{2}{|r|}{ Sistem Model (EfficientNet) } & $\mathbf{5}$ & $\mathbf{7 9 . 8 \%}$ \\
\hline
\end{tabular}

Walaupun akurasi pada model (Nikhil, 2019) sebesar $80.1 \%$, namun dataset yang digunakan sedikit yaitu 100 untuk tiap kelas nya. Hal ini akan menyebabkan terjadinya penurunan akurasi jika dataset baru diperbanyak. Selain itu sistem model pada penelitian ini memiliki peningkatan nilai akurasi, yaitu sebesar $79.8 \%$ dibandingkan dengan model lainnya yang dapat mengklasifikasikan 5 kelas Diabetic Retinopathy.

\section{KESIMPULAN}

Setelah melakukan pengujian dengan menggunakan 4 skenario, maka dapat disimpulkan bahwa EfficientNet dapat meningkatkan akurasi untuk mengklasifikasi 5 level Diabetic Retinopathy dibandingkan dengan model lainnya. Setelah dilakukan preprocessing menggunakan CLAHE pada penelitian ini, akurasi meningkat yaitu bertambah menjadi $79.8 \%$. Ukuran citra mempengaruhi nilai akurasi, oleh karena itu tidak disarankan untuk merubah ukuran citra menjadi lebih kecil atau besar dari citra aslinya. Menggunakan optimizer SGD dengan learning rate 0.001 dan momentum 0.9 , serta categorical crossentropy sebagai lossnya didapatkan akurasi sebesar $79.8 \%$ dengan specificity dan sensitivity sebesar $93.11 \%$ dan $80 \%$.

Untuk penelitian lebih lanjut, disarankan untuk menggunakan jumlah dataset yang seimbang antar kelasnya. Seimbang berarti setiap kelas pada dataset memiliki jumlah yang tidak jauh berbeda atau sama. Misalkan kelas A memiliki 1000 data, maka kelas B, C, D juga sebaiknya memiliki data 1000. Hal ini sangat membantu sistem untuk menghindari melatih hanya kelas yang dominan. Selain itu diperlukan sebuah metode preprocessing lainnya agar sistem lebih mengenali citra lebih baik lagi.

\section{DAFTAR RUJUKAN}

Ahmadi, M., Vakili, S., Langlois, J. M. P., \& Gross, W. (2018). Power Reduction in CNN Pooling Layers with a Preliminary Partial Computation Strategy. 2018 16th IEEE International New Circuits and Systems Conference, NEWCAS 2018, (pp. 125-129).

Albawi, S., Mohammed, T. A., \& Al-Zawi, S. (2018). Understanding of a convolutional neural network. Proceedings of 2017 International Conference on Engineering and Technology, ICET 2017, (pp. 1-6). 
Campos, G. F. C., Mastelini, S. M., Aguiar, G. J., Mantovani, R. G., Melo, L. F. de, \& Barbon, S. (2019). Machine learning hyperparameter selection for Contrast Limited Adaptive Histogram Equalization. Eurasip Journal on Image and Video Processing, 2019, (1), 118.

Duh, E. J., Sun, J. K., \& Stitt, A. W. (2017). Diabetic retinopathy: current understanding, mechanisms, and treatment strategies. JCI Insight, 2(14), 1-13.

Gonzalez, R. C. (2018). Deep Convolutional Neural Networks [Lecture Notes]. IEEE Signal Processing Magazine, 35(6), 79-87.

Nikhil, M. N., Angel, R. A. (2019). Diabetic Retinopathy Stage Classification using CNN. International Research Journal of Engineering and Technology, 6(5), 5969-5974.

Pratt, H., Coenen, F., Broadbent, D. M., Harding, S. P., \& Zheng, Y. (2016). Convolutional Neural Networks for Diabetic Retinopathy. Procedia Computer Science, 90, (pp. 200205).

Qidong, L., Yingying, L., Zhilian, Q., Xiaowei, L., \& Yun, X. (2020). Speech Recognition using EfficientNet. Proceedings of the 2020 5th International Conference on Multimedia Systems and Signal Processing, (pp. 64-68).

Qomariah, D. U. N., Tjandrasa, H., \& Fatichah, C. (2019). Classification of diabetic retinopathy and normal retinal images using CNN and SVM. Proceedings of 2019 International Conference on Information and Communication Technology and Systems, ICTS 2019, (pp. 152-157).

Qummar, S., Khan, F. G., Shah, S., Khan, A., Shamshirband, S., Rehman, Z. U., Khan, I. A., \& Jadoon, W. (2019). A Deep Learning Ensemble Approach for Diabetic Retinopathy Detection. IEEE Access, 7, 150530-150539.

Tan, M., \& Le, Q. V. (2019). EfficientNet: Rethinking model scaling for convolutional neural networks. 36th International Conference on Machine Learning, ICML 2019, 2019-June, (pp. 10691-10700).

Wang, X., Lu, Y., Wang, Y., \& Chen, W. B. (2018). Diabetic retinopathy stage classification using convolutional neural networks. Proceedings - 2018 IEEE 19th International Conference on Information Reuse and Integration for Data Science, IRI 2018, (pp. 465-471).

$\mathrm{Wu}$, L. (2013). Classification of diabetic retinopathy and diabetic macular edema. World Journal of Diabetes, 4(6), 290-294.

Yadav, G., Maheshwari, S., \& Agarwal, A. (2014). Contrast limited adaptive histogram equalization based enhancement for real time video system. Proceedings of the 2014 
Deep Learning untuk Klasifikasi Diabetic Retinopathy menggunakan Model EfficientNet

International Conference on Advances in Computing, Communications and Informatics, ICACCI 2014, (pp. 2392-2397).

Zebin, T., Scully, P. J., Peek, N., Casson, A. J., \& Ozanyan, K. B. (2019). Design and Implementation of a Convolutional Neural Network on an Edge Computing Smartphone for Human Activity Recognition. IEEE Access, 7, 133509-133520. 